\title{
MOTIVATIONAL COMPONENT OF NATIONAL CORPORATE SOCIAL RESPONSIBILITY: FUNDING, ACCOUNTING AND REPORTING ASPECTS
}

\author{
Olha Osadcha* \\ National University of Water and Environmental Engineering \\ Olha Pavelko \\ National University of Water and Environmental Engineering \\ Joanna Nakonieczny \\ Rzeszow University of Technology \\ Oksana Zinkevych \\ National University of Water and Environmental Engineering
}

\begin{abstract}
The article describes accounting assurance for payroll payment in national company under modern business conditions. The purpose of research is to identify methods for social protection of employees, being the vital element of sustainable business activity. The issues of statutory and accounting regulations for payroll payment and other fringe benefits have been generalized; their alternative solution has been given. Distinguishing features of payments specified in national comparing to international accounting standards have been researched. Practical approaches to funding of motivational component for social protection of personnel in national business company have been analyzed. Considering current requirements of national accounting standards, the improvement in analytical accounting of accruals and payments to employees (compensatory as well as motivational benefits) have been suggested. These ideas will allow us to expand informational capacity of accounting assurance for fringe benefits and their types, monetary evaluation, employee categories etc. All the above mentioned will give the opportunity to control methods of organization and owner's regulatory compliance of corporate social responsibility.
\end{abstract}

Keywords: Companies; Employee benefits; Payroll payments; Business activity; Accounting and analytical assurance.

Received: 8 January 2019

Accepted: 11 September 2020

\section{INTRODUCTION}

Ukraine, as a market economy country, has provided favorable investment conditions in recent decades, creating a stable, predictable market for expanding the business and establishing

\footnotetext{
*Corresponding author: National University of Water and Environmental Engineering, O. Novaka Street, 75, Rivne, 33002,
} Ukraine; Tel.: +380677397390; Email: o.o.osadcha@nuwm.edu.ua 
cooperation with foreign investors. The outlined and declared by Ukraine direction for integration with European countries and the world economic system, the active development of Ukrainian business sets new tasks for domestic enterprises, which are connected with the intensification of processes in the sphere of social responsibility in Ukraine.

Our study will be centered on Ukraine, a country, where the social responsibility of business is a new concept for the economy.

In recent years, the concept of social responsibility of business has become widespread in Ukraine, which is a system of social relations with interest groups (stakeholders), interaction with the state in solving social problems. Social responsibility not only improves the image of the enterprise, but it also provides access to new markets and gains competitive advantages over the long run.

Given the fact that Ukraine has chosen European integration as a priority area over the medium and long term, Ukrainian business must focus on European standards first and foremost. Launched in 2006, the European Alliance for Corporate Social Responsibility has defined social responsibility as a concept of engaging social and environmental trends in business activities on a voluntary basis and interaction between all stakeholders (influence groups).

According to the developed Strategy for promoting the development of social responsibility of business in Ukraine for the period up to 2020, the need for development of social responsibility of business in Ukraine is due to such factors like low level of corporate culture and awareness of society of the role of business; legal nihilism and deformation of legal consciousness; terminological (regulatory) uncertainty; the closed nature of Ukrainian companies to the general public; unequal consideration of stakeholder interests, etc.

With the development of the economy, stabilization of the monetary, credit, fiscal, monetary sphere in Ukraine, the formation and development of social policy of the state takes place, including the system of social protection of the population in order to compensate for the negative manifestations of a market economy. During the years of independence (since 1991), a policy of social protection, population insurance and the proper conditions for its functioning were developed and implemented in Ukraine. However, at the same time, the social sphere is imperfect and in many respects does not meet the current demands of the population. Therefore, the state faces a number of problematic issues, including the transition from benefits and grants to targeted financial assistance, expansion of the network of non-state pension funds, a prudent policy in the area of labor market regulation, remuneration, and the entire social security and population protection.

Business as part of society cannot act in isolation from society. The economic activity of enterprises determines the state of the environment to a large extent, undoubtedly affecting the quality of consumer goods and services. The social orientation of business will be systemic and more effective if, in the overall strategy of enterprise management, its social responsibility becomes a priority.

Companies of Ukraine as well as the enterprisers of other countries of the world are increasingly focused toward motivational component of national corporate social responsibility all the while resolving to maximize economic performance in order to satisfy shareholders and act in a socially 
responsible manner for the benefit of society as a whole. Social, economic and environmental concerns are forcing companies to integrate systems that take into account the observance of the law in all spheres, and also focus on the common good for society in general and stakeholders in particular (Rodriguez-Fernandez, 2016).

The importance of the problem that includes payroll payments regulations as well as other benefits under developing The Concept for sustainable national social and economic growth is undeniable. Since labor payment is a vital element in social and labor relations. Payroll accounting, adequate assessment of labor resources (quantity and quality indexes), efficient organization of integrated accounting for business activity of the entity (financial, tax and managerial accounting subsystems) are of great value for providing sustainable use of manufacturing resources (labor, in particular).

Considering the scientific and practical value of the results obtained, further research is necessary in accounting and managerial assurance of current conditions for labor potential motivation in national enterprise, taking into account international requirements for sustainable social and economic as well as ecological element in business activity.

Some research has focused on the positive relationship between corporate social responsibility and financial performance, but there is a lack of homogeneity in the results (Gjølberg, 2009). It is determined that financial performance depends on corporate social responsibility (RodriguezFernandez, 2016; Vveinhardt \& Andriukaitiene, 2017; Sukserm \& Takahashi, 2011.).

Presently corporate social responsibility and business ethics are intricately related from both an academic and practical perspective. A variety of corporate social responsibility definitions proposed in the literature and by several institutions that emphasize a voluntary involvement in the solution of certain social issues is considered; social responsiveness is fundamentally multidimensional and embodies a large and varied range of corporate behavior in relation to its resources, processes and outputs (Waddock \& Graves, 1997).

Shareholders require efficiency of managers, in order to ensure the continuity of the company over the long term, whilst demanding that socially responsible policies be integrated into the companies themselves (Vasilescu, Barna, Epure, \& Baicu, 2010).

Notably, previous studies have been conducted to explore the corporate social responsibility factors influencing the financial performance.

The purpose of research is to analyze theoretical and practical aspects of describing measures for social protection of employees in business accounting system in order to give full information to the users of reporting. The information should include: owner's regulatory compliance of corporate social responsibility, developing monitoring system for economic assurance of social protection and ecological safety (using personnel potential, in particular). The target of research is the payments to employees, consisting of benefits as fundamental and motivational elements. The subject of research is theoretical, methodical, organizational and managerial approaches to organization and accounting of payments to employees based on sustainable use of labor resources.

For solving the tasks, general scientific and special methods of cognition are used: dialectical method of cognition (in the study of the genesis of coverage of corporate social responsibility in 
the works of scientists from different countries of the world), induction (in the study of the data of 16 Ukrainian enterprises and drawing conclusions on the basis of the structure of the social package of Ukrainian enterprises in general) and deduction (in the projecting of general global patterns of development of social corporate responsibility from the experience of the countries of the world onto Ukraine), theoretical comparison (in representing employee benefits data under GAAP 26 "Employee benefits" and IAS 19 "Employee benefits"), observation (in the study of the activity, in particular, social component, gas supplying energy companies, chemical industry enterprises, milk plant and two bakery manufacturing plants, banking institution), system analysis and synthesis (in the study of the legislation of Ukraine regulating payments to employees), graphic method (in building the Block diagram of the algorithm for constructing an integral indicator for assessing the effectiveness of an enterprise).

In 2018, in order to identify the importance of social indicators in assessing the performance in general, as well as understanding the structure of the social package, we conducted a survey among the chief accountants and management of 16 Ukrainian enterprises representing different types of activities - gas supply and power supply companies, chemical industry enterprises, dairy factory and two bakery factories and banking institution. The main results of this study are the basis of this article.

\section{LITERATURE REVIEW}

During the second half of the $20^{\text {th }}$ century, the evolution of CSR as both practice and concept was in the focus of the academic literature.

The publication of the Corporate Report (ICAEW, 1975) caused a significant revival in the disclosure of social information by enterprises worldwide. The importance of forming external and internal communications between stakeholders and enterprises in the area of social information analysis is emphasized in the report of the European Commission (EC, 2002) and in the works of Chen, Dong \& Lin, 2019; Park, Meglio \& Schriber, 2019; Stahl, Brewster, Collings \& Hajro, 2019.

The hypothesis that the advantage of corporate social performance yields in attracting the human resources depends on the degree of job choice possessed by the job seeking population is investigated by Albinger and Freeman (2000). Five dimensions of CSR are developed through a content analysis of existing CSR definitions (Dahlsrud, 2008) and it is concluded that the confusion is not so much about how CSR is defined, as about how CSR is socially constructed in a specific context. A new methodological and theoretical framework for assessing and explaining the sustainability impact of CSR is built by Barth and Wolff (2009).

The companies that have the best perceived images (in terms of admiration, reputation and brand value) as reflection of their approaches towards CSR; the strategic value of the global winners' CSR involvement as perceived through external lens - consumers, executives, directors and analysts are identified, based on a comparative analysis (Carroll, 1999; Ogrean, 2014; Orlitzky, Schmidt \& Rynes, 2003). The results of its own original research investigated by the utilization rate of corporate websites for the comprehensive communication about socially responsible 
activities, inclusive of the main determining factors, is described by Kunz, Ferencová, Hronová \& Singer (2015). CSR is regarded as a system of management which consists of inputs, process, and outputs. The process includes management functions of planning, organizing, actuating and controlling (Krisnawati, Yudoko \& Bangun, 2018; Mahoney \& Thorne, 2005).

One of the most popular definitions of corporate social responsibility (CSR) in practical activity of national enterprise is a responsible attitude to your product or service, to your customers, employees and partners; being socially minded, which means coexisting, cooperating and communicating with society (Frederick, 2018; Luo \& Bhattacharya, 2006). In addition, efficient motivation of national business in terms of practical realization in the targeted directions on owner's (CEO) level as well as state level is still rather important.

CSR is considered in the areas of international business, marketing, strategic management (Blowfield \& Murray, 2011; Mohamed Adnan, Hay \& van Staden, 2018; Xiao, Cooke, Xu \& Bian, 2019). Maintaining a link between CSR and strategic management, Grover, Kar and Ilavarasan (2019) emphasize that "the activities of CSR are part of the strategic initiatives of companies".

In an organization, motivation is based on defining the employees' motives reflecting the fulfillment of internal needs and impulses that the employees try to pursue while working in an organization. Employees' motives are determined by personal values and convictions, as well as by the understanding of their place in the organization. The basic needs, as the foundation of motives, were emphasized in classical content theories of motivation by the effort's ability to satisfy some individual need. (Aliekperova, 2018).

Users of business financial reporting in Ukraine tend to follow rules and regulations set out by the On Remuneration of Labour Act of Ukraine (On Remuneration of Labour Act: The Law of Ukraine of March 24 ${ }^{\text {th }}$, 1995), the Code of Labour Laws of Ukraine (Code of Ukraine: approved by the Law of Ukraine of December 10 $\left.0^{\text {th }}, 1971\right)$. These regulations had been developed before world markets implemented principles of «motivational/compensational element of social protection for labor resources», «environmentally friendly surrounding», «social and economic sustainability» etc.

Unfortunately, there are still some unresolved issues concerning employee payments, such as:

1. Low level of minimum wages: the pay rise in 2017 under financial insecurity of enterprises (public, in particular) has caused «the equality» in terms of payroll payments, without taking into account qualification level as well as competence category of employees. The methods of calculation the minimum living standard for the labor pool (according to the minimum wages) are still unjustified.

2. Low level of labor payments (in the industrial area, first of all): the majority of national manufacturers produce raw materials and semi-processed products, which don't require qualified labor to be involved. It results in low added value of local production (which, obviously, stipulates low wages).

3. Applying ungraded personal income tax (18\%) that influences negatively over social environment on the whole: according to the public opinion poll, due to the increase of financial security for population, people regard the measures of state regulation in national social and economic development with growing distrust. 
In the Code of Labour Law of Ukraine (passed through its second reading) (The Code of Labour Law of December $27^{\text {th }}, 2014$ ) the issues of legislative regulation for some compensational payments have been defined (particularly, taking leaves, financial aids, providing employees with therapeutic food products, etc.).

Unfortunately, in the Code of Labour Law Draft most of social benefits (except wages and fringe benefits) are not obligatory; they are left at employer's will.

Let's look at national and overseas practice of «corporate social responsibility» (CSR) as the subject for state regulation and one of the conditions for the company competitiveness. The main targets of overseas corporate social responsibility are regulated in the Concept at state level as well as at the company level, that declares:

1. Business should function with a strong determination to protect and develop the interests and welfare of community.

2. Any revenue received should not be its ultimate goal.

3. Business should be faithful in the performance of its duty to develop the welfare of community, and all its resources and facilities should receive high rates of income.

4. Business cannot disclaim responsibility for the community where it prospers (Kot, 2014; Turker, 2008).

The inherency of the CSR policy is the most obvious; it is obtained through a clear duties regulation: business must provide distributed profit to shareholders or investors; it must provide decent wages and appropriate working conditions, the supply of quality products/services to the customers on a regular basis for reasonable prices; business must follow all government principles and regulations, support national business policy, it must pay fair taxes without delays or levies, business must also contribute the development of the local community, taking up such projects as construction of schools, colleges, hospitals, etc.; business activity mustn't directly or indirectly harm the residential surrounding of the environment; business must support a rigorous policy for air, water, ground pollution restriction or control as well as sound or radiation pollution; business entity must provide community with the service of social assurance.

At the moment, types (forms) of CSR in Ukraine have not been developed (as well as the motivation for their implementation).

In international business practice there are four main types of CSR:

- $\quad$ economic, primary responsibility, that is to say, a company should create workplaces, and pay taxes to contribute into country's development;

- $\quad$ legal responsibility, company should comply with national and international law;

- $\quad$ ethical responsibility, a company and all its employees should follow the code of ethics when interacting with each other, competitors, the state and community (Crestofel, Shaniqua, Pulungan\&Yudiarti, 2017; Nwabueze\&Mileski, 2018).

In Ukrainian laws and regulations, only economic and legal responsibilities are described (they are not always obligatory but rather dependent on business financial profit, though). By contrast, ethical responsibility is not mentioned at all. Ethical approaches involve eliminating corruptive, irresponsible and unethical behavior that can harm society or environment. Implementing ethical decisions to increase labor capacity, using financially supported programs will allow employees to feel their ability to influence the image and benefits of the company. 
One more responsibility is philanthropic responsibility; it is also not mentioned in Ukrainian laws and regulations.According to international business practice this type of responsibility is considered to be the highest level of responsibility. It involves investing in the projects that significantly benefit society, but are not profitable (such as, environmental protection, donating to health and educational facilities, infrastructure, campaigns against poverty) (Osadcha \& Svirko, 2014; Oliinyk, 2017; Mauricio Andrés, Lára, Brynhildur, 2019), or those ones with prevailing social goals comparing with economic interests, for instance, social entrepreneurship (Bilan, Mishchuk, \& Pylypchuk, 2017).

Without doubt, CSR efficiency should be assessed and motivated by external control authorities. For example, three-dimensional concept model of CSR efficiency is suggested. According to the model, there should be four categories of obligations: economical-legal-ethical dispositional structure, which is basically economic activity. The main responsibility here is economical, which also correlates with all laws. Ethical responsibilities are the principles, that the company is expected to follow even if they are not described in the entity's regulations or competence. The four categories are not mutually exclusive and can be described in the form of CSR pyramid.

Nowadays, current Tax Code of Ukraine doesn't encourage taxpayers to participate in «philanthropic» (charitable) activity.

The recognition of the enterprise as being «socially responsible» is an important factor of competitiveness. World business practice considers the higher level of social responsibility to be «philanthropic or corporate social responsibility (CSR)»: investing into projects, that benefit the community, but are not profitable; environmental protection; investments into health care, education, infrastructure, etc.

Big American and European business has been known as pragmatic, but it recognizes the positive influence of CSR on the image of the enterprise:

- the loyalty of consumers along with the brand value increase. The research shows that CSR influences $70 \%$ of European consumers' choice of brand when shopping. One out of five Europeans is willing to pay more for environmentally-friendly product as well as for other elements of CSR.

- $\quad$ efficient and fair lobbying is observed, having trust and support of community. For example, western electric power companies, which are monopolies on certain territories, invest into economic development of these territories and into non-profit «green» sources of energy. But, when there is a need to increase tariffs for population, they receive a positive support of community and politicians-quality and motivation of the staff increase. The research shows that companies, which pay attention to CSR, can train employees that are more motivated and less willing to take advantage of the company for personal gain (Porter \& Kramer, 2006).

\section{METHODOLOGY}


In the course of this study, it was found that social indicators are not prioritized when evaluating their activities for Ukrainian enterprises. We used the results of the survey and processing of information on the importance of indicators as components of the evaluation of the efficiency of 16 enterprises. The selected enterprises represent different branches of the national economy: gas supply, electric power transmission, production of radiators and central heating boilers, production of fertilizers and nitrogen compounds, production of cement and its wholesale trade, production of glass containers, production and sale of bakery products, dairy products. Their common features are the location, which is Western Ukraine, and the size - they all belong to large and mediumsized enterprises (according to Ukrainian law, medium-sized enterprises are enterprises which meet at least two of the following criteria: book value of assets is up to 20 million Euros, net income from sales of products (goods, works, services) is up to 40 million Euros, average number of employees is up to 250 persons; large enterprises meet at least two of the following features: book value of assets is more than 20 million Euros, net income from sales of products (goods, works, services) is more than 40 million Euros, average number of employees is over 250 persons). This choice was made in view of the fact that in such enterprises, given the available financial resources, certain measures could be taken to implement the corporate social responsibility system. In addition, the information for our study was summarized through questionnaires (oral and written) and generalization of financial and statistical reporting, that is why it was more convenient to conduct it in Western Ukraine, given the territorial proximity of all the economic entities surveyed.

The general scheme of the developed approach consists of 3 stages:

1. Ranking of indicators based on the benefits of experts.

2. Construction of mathematical models based on fuzzy logic to assess the directions of the enterprise.

3. Calculation of the index of the enterprise - an integral indicator, which takes into account both the importance of directions and their state.

A detailed scheme for constructing an integral indicator of performance evaluation is depicted in Fig. 1

Prior to the start of the study, a set of the baseline indicators was selected to test the approach being developed.Note that the indicators with a $(+)$ mark on the survey results were selected to build the model. The indicators were selected taking into account the conceptual provisions of the theory of sustainable development: the combination of economic, environmental and social components ensures the sustainable development of the enterprise, maximizes the efficiency of its activity in current conditions. The list of indicators was selected by the authors on the basis of the study of the works of leading foreign and domestic scientists on economic analysis, generalization of national regulatory documents which regulate the methodology of analytical procedures for the efficiency of economic entities, namely: Methods of integrated assessment of investment attractiveness of enterprises and organizations, Methods of assessment of effectiveness of implementation of regional environmental and state (national) targeted environmental programs, Regulations on the procedure for analyzing the financial condition of enterprises subjected to privatization. Furthermore, during the selection of the indicators, the indicators were used which are represented in the regional Programs of social and economic development, which stipulate the stable development of regional enterprises, their financial and organizational support in the context of territorial reform. 
1. Economic $(\mathrm{F})$ :

f1 - Excess of assets over authorized capital

$\mathrm{f} 2$ - The ratio of financial leverage

f3 - Return on assets $(+)$

f4 - Return on equity $(+)$

f5 - The average number of employees

f6 - The coefficient of financial dependence

f7 - Permanent asset index

f8 - Factor ratio of material non-current assets to equity

f9 - Coefficient of stock coverage of net working capital $(+)$

f10 - Current liquidity ratio $(+)$

f11 - Absolute liquidity ratio

f12 - Return on assets $(+)$

f13 - Capital-output ratio

f14 - Labor productivity $(+)$

f15 - Participation in innovative projects $(+)$

2. Ecological (E):

e1 - Product Safety Ratio (+)

e2 - Ecological ballast coefficient $(+)$

e3 - Ratio of waste management $(+)$

e4 - Cost-effectiveness of waste products $(+)$

e5 - Environmental pollution factor $(+)$

3. Social (S):

s1 - The share of labor protection costs in the entity's operating expenses $(+)$

s2 - Injury rate per 100 people $(+)$

s3 - Number of days of temporary disability per 100 people

s4 - Percentage of workers with occupational diseases

s5 - Percentage of total morbidity of employees

s6 - Share of days of occupational diseases (number of days / 365)

s7 - Number of issued permits for sanatorium treatment / average number of employee for the reporting period

s8 - The share of employees provided with departmental housing

s9 - The number of appeals by workers in trade unions / average number of employee $(+)$

s10 - Costs for the purchase of departmental housing / total expenses for the reporting period.

s11 - The share of workers who changed the place of work within the company / average number of employees for the reporting period $(+)$

s12 - The share of workers with higher education in the average number of employees $(+)$ s13 - The share of workers who increased their qualifications during the year in the average number of employees for the reporting period $(+)$

s14 - Average monthly number of cultural events (number / 12)

s15 - The ratio of average wages by the company to the highest salary. 
Figure 1: Block Diagram of the Algorithm for Constructing an Integral Indicator for Assessing the Effectiveness of an Enterprise

1. Formation of a set of activitvspheres

2. Formation of the most complete set of parameters describing each sphere

3. Classification of indicators within each of the spheres and ranking

\begin{tabular}{|l|l|l|}
\hline 1 & $n$ & 1 \\
\hline 7 & 1 & $?$ \\
\hline 1 & $n$ & 1 \\
\hline
\end{tabular}

\begin{tabular}{|l|l|l|}
\hline 1 & $\cap$ & 1 \\
\hline 7 & 1 & $?$ \\
\hline 1 & $\cap$ & 1 \\
\hline
\end{tabular}

\begin{tabular}{|l|l|l|}
\hline 1 & $n$ & 1 \\
\hline 7 & 1 & $?$ \\
\hline 1 & $\cap$ & 1 \\
\hline
\end{tabular}
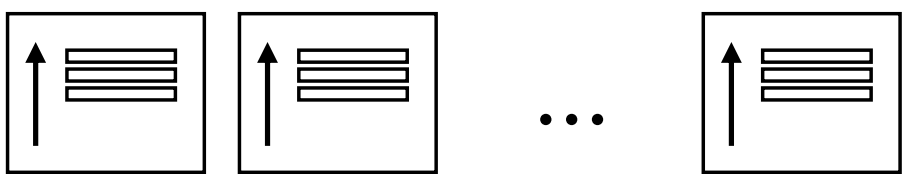

4. Selection of the most important rank-based indicators

5. Construction of models for each of the spheres based on the expert rules with fuzzy logic use
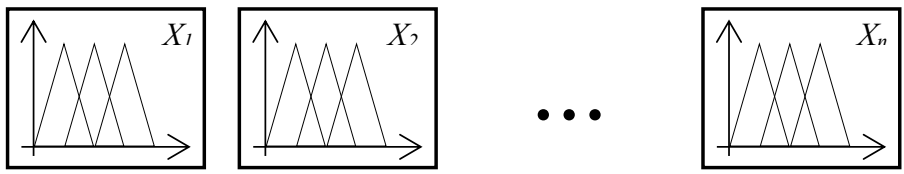

6. Ranking of activity spheres based on the method of pairwise comparison and weighting: $A_{1}, A_{2}, \ldots, A_{n}$

7. Formation of the general form of the integral index by the formula:

$$
I_{c}=A_{1} X_{1}+A_{2} X_{2}+\ldots+A_{n} X_{n}
$$

\section{RESULTS AND DISCUSSION}

As a result of the conducted research data were obtained, on the basis of which the above economic, environmental and social indicators for each of the surveyed enterprises were calculated. In our view, usage of accurate mathematical models to evaluate the performance of econometrics, neural 
networks, or other approaches confirms the need for sufficiently detailed accounting data to be disclosed in financial reporting forms either directly or through summary procedures. In the enterprise information environment, such information can have a number of disadvantages, such as: inaccuracy, incompleteness, insufficient data to build a model, etc. In uncertainty, where information is not adequately described by quantitative indicators, methods are used that take into account the knowledge and experience of decision-makers. The enterprises may include directors, heads of departments, leading specialists and other professionals in the chosen field.

The obtained results are processed using the developed algorithm in the $\mathrm{R}$ language. The results of calculations are given in Tables 1-4.

Table 1: Estimated Ranks and Importance of Economic Indicators

\begin{tabular}{ccccccccc}
\hline \hline Name & Value & Rank & Name & Value & Rank & Name & Value & Rank \\
\hline f1 & 0,0669 & 7 & $\mathrm{f6}$ & 0,0654 & 8 & $\mathrm{f} 11$ & 0,0671 & 6 \\
$\mathrm{f} 2$ & 0,0616 & 10 & $\mathrm{f} 7$ & 0,0497 & 12 & $\mathrm{f} 12$ & 0,0709 & 3 \\
$\mathrm{f3}$ & 0,0673 & 5 & $\mathrm{f} 8$ & 0,0635 & 9 & $\mathrm{f} 13$ & 0,0555 & 11 \\
$\mathrm{f} 4$ & 0,0673 & 5 & $\mathrm{f} 9$ & 0,0673 & 5 & $\mathrm{f} 14$ & 0,0738 & 2 \\
$\mathrm{f5}$ & 0,0635 & 9 & $\mathrm{f} 10$ & 0,0708 & 4 & $\mathrm{f} 15$ & 0,0895 & 1 \\
\hline \hline
\end{tabular}

Table 2: Estimated Ranks and Importance of Environmental Indicators

\begin{tabular}{ccc}
\hline \hline Name & Value & Rank \\
\hline e1 & 0,1643 & 4 \\
e2 & 0,1840 & 3 \\
e3 & 0,1895 & 2 \\
e4 & 0,1520 & 5 \\
e5 & 0,3102 & 1 \\
\hline \hline
\end{tabular}

Table 3: Estimated Ranks and Importance of Social Indicators

\begin{tabular}{ccccccccc}
\hline \hline Name & Value & Rank & Name & Value & Rank & Name & Value & Rank \\
\hline s1 & 0,0707 & 5 & s6 & 0,055 & 13 & s11 & 0,0745 & 4 \\
s2 & 0,0684 & 6 & s7 & 0,0578 & 11 & s12 & 0,0894 & 2 \\
s3 & 0,0671 & 7 & s8 & 0,0575 & 12 & s13 & 0,0643 & 8 \\
s4 & 0,0613 & 9 & s9 & 0,0768 & 3 & s14 & 0,0433 & 15 \\
s5 & 0,0553 & 14 & s10 & 0,0612 & 10 & s15 & 0,0972 & 1 \\
\hline \hline
\end{tabular}

Table 4: Estimated Ranks and Importance of Business Areas

\begin{tabular}{ccc}
\hline \hline Name & Value & Rank \\
\hline $\mathrm{F}$ & 0,6011 & 1 \\
$\mathrm{E}$ & 0,1694 & 3
\end{tabular}


Thus, the calculations carried out show that social indicators occupy the second place in importance in assessing the results of the business areas.

Nowadays accounting and financial statements data is not sufficient source of information anymore when it comes to making strategic or operational managerial decisions: the advantages of management accounting are not properly regulated in legislation; methodical basics of (internal) accounting should be further harmonized with settlements of budgetary payments accounting (Berling, 2012).

The need for adding such indexes as: generating and protecting human capital; corporate management of the personnel development; pollution as a result of enterprise activity, etc. to the existing forms of financial accounting becomes obvious. Let's take, for example, the indexes of social security considering international practice of non-profit business units. In general, all indexes of business social responsibility can be divided into four blocks: health safety;corporate culture development;training, professional development;recreation and entertainment;labor motivation. The indexes of business social responsibility are given below.

When identifying corporate social responsibility as a subject for accounting, system monitoring and control in national companies, it is appropriate to focus on the main directions of economy providing social protection for employees and efficient influence of business performance on sustainable economic development.

Social protection for employees is a complex program for reproduction, preservation and development of labor resource through implementation of basic and motivational components of benefits package.

Table 5: Indexes of social responsibility in financial statements of domestic businesses 


\begin{tabular}{|c|c|c|c|c|c|}
\hline $\begin{array}{l}\text { Indexes of business social responsibility (in } \\
\text { the accounting period)* }\end{array}$ & $\begin{array}{c}\text { Financial } \\
\text { statements }\end{array}$ & $\begin{array}{c}\text { Reports for } \\
\text { social security } \\
\text { administration }\end{array}$ & $\begin{array}{l}\text { Statistical } \\
\text { reports }\end{array}$ & $\begin{array}{c}\text { Settlements } \\
\text { of } \\
\text { budgetary } \\
\text { payments }\end{array}$ & Notes** \\
\hline 1 & 2 & 3 & 4 & 5 & 6 \\
\hline \multicolumn{6}{|l|}{ health safety $* * *$} \\
\hline - workers' compensation & + & & + & + & \\
\hline - expenditure on labor protection & + & & & + & \\
\hline - the number of occupational injuries & & + & & & \\
\hline $\begin{array}{l}\text { - the number of days off work due to injury } \\
\text { or illness }\end{array}$ & & + & & & \\
\hline $\begin{array}{l}\text { - the number of days off due to occupational } \\
\text { illness }\end{array}$ & & + & & & \\
\hline - the number of sanatorium-resort therapy & & + & & & \\
\hline
\end{tabular}

\section{Satisfyingsocialwelfareneeds}

- the number of employees in the employer

assisted housing list

- seating capacity in the canteen

- the number of employees granted housing

- the number of employee applied to the trade

union organizations

- expenditure on employees' housing +

arrangements

- expenditure on housing rent compensation

- financial aid to employees

training, professional development

- expenditure on employees' professional

development

- expenditure on employees' training

- the number of employees with higher

education (divided into categories)

- the number of employees who had taken

their course of professional development

\section{recreation and entertainment}

- expenditure on tourist tours

- expenditure on public events

labor motivation
- average salary (divided into categories)
- additional vacation pay expense
- bonuses

Notes: *compiled on the basis of (Indexesofbusinesssocialresponsibility), ** at the moment the column is left empty, the reports require additional information, $* * *$ it is appropriate to apply relative indexes (due to the proportion of researched index to its general sum/amount of expense, number of workers, etc.).

Considering business practice in Ukraine, benefits package can be classified into basic and motivational. Basic benefits package is the guarantees regulated by Ukrainian legislation and labor contract, that involve providing essential working conditions (environmentally friendly, in the first place), described in labor legislation, collective employment agreement and mutual agreement of the parties; compulsory state social insurance; full payroll payment; providing fringe benefits and guarantees, regulated by collective employment agreement (industrial agreement). Motivational benefits package combines competitive (developing motivational system for employee willing to 
apply their professional potential) and compensation package (financial consideration, provided to the employee by the employer beyond those benefits regulated in legislation).

International practice includes motivational component, consisting of four blocks, into basic benefits, such as health care, corporate culture development, training and continuing professional development, recreation and leisure, labor motivation. We conducted the survey of business companies in Western Ukrainian region (as a part of the survey of 16 enterprises). The results present the content of benefits package (except basic elements) consisting of the following fringe benefits: reimbursements for mobile communication, trainings (seminars), commuting expenses, health care insurance, holiday presents, car rent, recreation expenses, office catering, life insurance, non-state retirement insurance, house rent expenses.

General structure of fringe benefits, resulting from the survey, is given in the Figure 2.

Figure 2: Reimbursements under fringe benefits of Western Ukrainian region companies, $\%$ (according to results of research conducted by the authors)

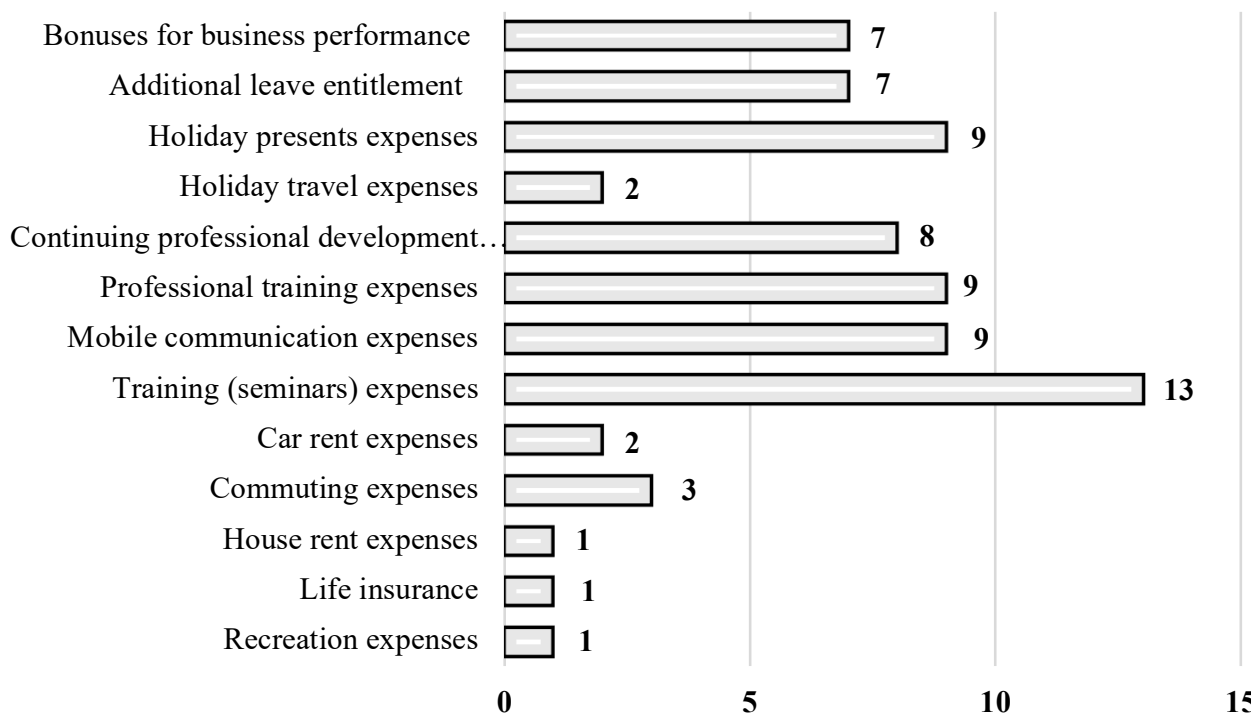

As we see, the largest share in the social package of the investigated enterprises (13\%) is the cost of paying for participation in seminars and trainings of workers in order to increase the efficiency of their work, improve the psycho-emotional climate. Paying for the training of employees in higher education institutions is $9 \%$ of the social package, the cost of services for advanced training is $8 \%$. Interestingly enough, the share of expenses for the paying of mobile communications is $9 \%$, the purchase of gifts for holidays is $9 \%$, travel expenses - 7\% (according to the management of enterprises, first of all, such travel trips were made to sanatoriums with therapeutic and recreational 
purposes), travel and work reimbursement - 3\%. The prize for the achievement of certain production figures was only $7 \%$ of the social package, which is not a negative sign in general. The smallest shares in social packages are paid for holiday expenses $(1 \%)$, housing rent compensation $(1 \%)$ and life insurance (1\%). In our opinion, it would be advisable to increase the share of expenses for the life insurance of workers by reducing the cost of participation in trainings, education and advanced training, as their share is too big (30\% - one third of the total social package).

In the course of the study, we made some theoretical generalizations, which are represented in tables 6 and 7 and Figure 3. Let's consider them in more detail.

Considering accounting assurance for payments, let's draw a comparison of international and national accounting practice for employee payments. Ukrainian Generally Accepted Accounting Principles (GAAP) 26 «Employee benefits»: Ukrainian Generally Accepted Accounting Principles 26 «Employee benefits»: Ukrainian Ministry of Finance Act of October 28 ${ }^{\text {th }}, 2003$ are based on approaches similar to International Accounting Standard 19 (IAS 19) «Employee benefits» (2012). (Table 6).

Table 6: Comparison of employee benefits under GAAP 26 «Employee benefits» and IAS 19 «Employee benefits»

\begin{tabular}{l}
\hline IAS 19 \\
1.Sort-term benefits: \\
- wages and salaries; \\
- social insurance benefits; \\
- paid vacation and sick leave; \\
- profit sharing and bonuses (if they are eligible to \\
be paid within twelve months after the end of the \\
working period); \\
- non-monetary benefits to current employees \\
(medical care, accommodation, cars, free and \\
subsidized goods and services). \\
\hline
\end{tabular}

\section{Post-employment benefits:}

- pensions;

- other retirement benefits;

- life insurance;

- medical care in the post-employment period;

\section{Other long-term benefits:}

- additional long-service leave;

- paid sabbatical leave;

- jubilee benefits, other long-service benefits;

- long-sick leave;

- profit sharing;

- bonuses and deferred compensation, if they are eligible to be paid after twelve months of the employment period or later.

\section{Termination benefits}

\section{GAAP 26}

\section{Current benefits:}

- fixed wages and salaries;

- other compensational benefits;

- compensated absences (annual vacations, other paid leaves);

- bonuses and other motivational benefits, that are eligible to be paid within twelve months after the end of working period);

\section{Post-employment benefits:}

the benefits (except termination and equity instruments benefits), that are eligible to be paid in the post-employment period

\section{Other long-term benefits}

the benefits (except post-employment, termination and equity instruments benefits) that are not eligible to be fully paid within twelve months after the month when the work has been completed.
4.Termination benefits
5.Equity instruments benefits 
the benefits, that give the right to receive financial equity instruments, issued by the company (or its parent), or the amount of the company's liabilities to the employee, which depends on the future price of financial equity instruments, issued by the company.

Some types of benefits are not mentioned in GAAP 26, although they are described in IAS 19. They can be regulatory applicable in Ukraine due to other legal documents, and they are applied quite often being initiated by the company. Equity instruments benefits are not described in IAS19; they are identified in GAAP 26, though.

The process for expanding types and forms of employee benefits under growing interest in work performance in our country is obvious. However, there is still a lot to improve in time performance of legislative regulation and practical efficiency of these methods. As a result, the issues of objective description of benefits paid to employees in the company's accounting system are mainstreamed. In national companies, basic benefits package is clearly regulated in the wages/salaries and fringe benefits. The obligation to pay the benefits is a subject to disciplinary and administrative action to the company's owner. To be able to pay, the owner is obliged to accumulate estimated amount from operating earnings.

Funding sources for the benefits are especially important (Table 7).

Table7: Funding sources for the benefits under national regulatory accounting requirements*

\begin{tabular}{|c|c|c|c|c|c|c|}
\hline \multirow[t]{2}{*}{ No. } & \multirow[t]{2}{*}{ Benefits elements } & \multicolumn{2}{|c|}{ Expenses } & \multicolumn{2}{|c|}{ Profit } & \multirow[t]{2}{*}{ Assurance } \\
\hline & & $\begin{array}{c}\text { Direct, } \\
\text { production, } \\
\text { manufacturing }\end{array}$ & $\begin{array}{c}\text { Operating } \\
\text { expenses }\end{array}$ & Retained profit & $\begin{array}{l}\text { Social } \\
\text { welfare } \\
\text { funding }\end{array}$ & \\
\hline 1 & 2 & 3 & 4 & 5 & 6 & 7 \\
\hline 1. & Basic benefits package & & & & & \\
\hline 1.1. & Wages/salary & + & + & $+* *$ & & + \\
\hline 1.2. & Extrafringe benefits & + & + & $+* *$ & & + \\
\hline 2. & $\begin{array}{l}\text { Motivational benefits } \\
\text { package }\end{array}$ & & & & & \\
\hline 1 & 2 & 3 & 4 & 5 & 6 & 7 \\
\hline 2.1. & Labour motivation & & + & + & + & \\
\hline 2.2 & Health care & & + & $+* *$ & + & \\
\hline 2.3 . & Socialwelfareservices & & & + & + & \\
\hline 2.4 & $\begin{array}{l}\text { Training, continuing } \\
\text { professional development }\end{array}$ & & + & $+* *$ & + & \\
\hline 2.5 . & $\begin{array}{l}\text { Recreation and } \\
\text { entertainment }\end{array}$ & & + & $+* *$ & + & \\
\hline
\end{tabular}

* GAAP in Ukraine;

**for the last fiscal year.

Let's discuss elements of motivational component from benefits package in details (Figure 3). 
The variability of funding sources stipulates the need for the company to launch monitoring and control of implementing preliminary approved programs for social protection in order to fund them. One of the factors for such monitoring is the implementation of analytical accounting of benefits by the funding sources, recipients, structural divisions, etc.

When forming analytical accounting of benefits, the sources of their generating (company expenses, assurance, and state social insurance costs), structure of benefits, regulated in legislation, employee categories, etc. should be considered.

Figure 3: Elements of motivational component in benefits package

Elements of motivational component in benefits package

\begin{tabular}{|c|c|c|}
\hline$\downarrow$ & $\downarrow$ & $\downarrow$ \\
\hline $\begin{array}{l}\text { Labour motivation: } \\
\text { - extrafringe } \\
\text { benefitstoaverag } \\
\text { ewages } \\
\text { (depending on } \\
\text { specific } \\
\text { categories of } \\
\text { employees); } \\
\text { - benefitsforadditi } \\
\text { onalleaveentitle } \\
\text { ments (exceptthe } \\
\text { leaves regulated } \\
\text { in legislation); } \\
\text { - bonuses }\end{array}$ & $\begin{array}{l}\text { Health care: } \\
\text {-compensated sick } \\
\text { leave; } \\
\text { - expensesforlabor } \\
\text { protectionfacilities; } \\
\text { the number of on-the- } \\
\text { job injuries; } \\
\text { - the number of } \\
\text { sick leave days; } \\
\text { - the number of } \\
\text { vocational illnesses } \\
\text { days; number of } \\
\text { - the num } \\
\text { treatment andiday } \\
\text { recreation holiday } \\
\text { tours }\end{array}$ & $\begin{array}{l}\text { Social welfare services: } \\
\text { - thenumberofemployeesin the } \\
\text { list for state accommodation; } \\
\text { - the number of seats in office } \\
\text { cafeteria; } \\
\text { - the number of employees } \\
\text { provided with the state } \\
\text { accommodation; } \\
\text { - the number of requests to } \\
\text { professional unions; } \\
\text { - purchase of state } \\
\text { accommodation expenses; } \\
\text { - houserentexpenses; } \\
\text { - financial aid }\end{array}$ \\
\hline \multicolumn{2}{|c|}{$\begin{array}{l}\text { Training, continuing professional } \\
\text { development: } \\
\text { - continuing professional development } \\
\text { expenses; } \\
\text { - professional training expenses; the } \\
\text { number of higher education employees } \\
\text { (depending on categories); } \\
\text { - the number of employees, having passed } \\
\text { continuing professional development }\end{array}$} & $\begin{array}{l}\text { Recreation and entertainment: } \\
\text { - holidaytravelexpenses; holiday } \\
\text { presents expenses; } \\
\text { - entertainment expenses (theatre, } \\
\text { concerts tickets, etc) }\end{array}$ \\
\hline
\end{tabular}

Can CSR be valuable for big business in Ukraine? It is obvious that today national business is struggling with distrust of population. For example, according to the Institute of Sociology 
research, only $19 \%$ of Ukrainians support taking public companies under private ownership. Considering low trust of population to business, its support in tax, currency, regulatory and other deregulation of economy can hardly be expected (Krepak, 2016).

\section{CONCLUSIONS}

The need to expand sustainable activity indexes in the forms of financial accounting for Ukrainian business is obvious. Thus, implementation of integrated accounting reporting becomes important. This system is not stipulated by the limitations of a certain accounting system, it can provide full information resulting from economic justification of social and ecological constituents' provision in business activities.

Dynamic development of entities involved in accounting implies for the accounting data to be specified, i.e additional analytics of financial accounts along with internal forms of accounting being introduced. The study, evaluation and comparison of indexes of Programs for economic development, social security and environmental safety implementation call for the necessity to create unified index, i.e. integrated index of sustainable activity.

Calculation objectivity as well as financial support of its implementation are important for the integrated index. National Accounting Standards of Ukraine offer a chance to cover the expenditure on implementation process of the above-mentioned Programs in a few alternative variants. Such expenses can be covered by:

- $\quad$ using other operational expenditure if analytic subaccounts are introduced in the columns of the Programs: Debit «Other operational expenses» - Credit «Resources (suppliers)»;

- $\quad$ using a fund created by means of retained profit account: Debit «Profit use» - Credit «Fund of sustainable activity»; Debit «Fund of sustainable activity» - Credit «Resources (suppliers)»;

- using reserve fund account for the Programs of sustainable operational activity implementation: Debit «Other operational expenses» - Credit «Reserves», Debit «Reserves»-Credit «Resources (suppliers)».

Unfortunately, in modern Ukraine, there are still a number of issues for systems of wages to be resolved. Methods for employee social assurance still need to be reformed, particularly motivational component of benefits package. However, the Code of Labour Law Draft, considering international practice in corporate social responsibility, doesn't involve all aspects of social assurance, which the employee may feel to be entitled to, due to fair assessment of their efforts and skills. Furthermore, in the Code Draft (as well as in the current Code of Labour Law) the requirements to providing employees with social protection by the employer, the types of social responsibility are not clearly regulated.

The methods, suggested in the article, for improving accounting and analytical support of payroll payments along with fringe benefits will promote efficient organization of labor use on the basis of corporate social responsibility in general.

Thus, the investigation contains a survey of chief accountants and management of 16 Ukrainian enterprises, using a block diagram of an algorithm for constructing an integral indicator for assessing the efficiency of enterprises. Ranks and meaning of the importance of economic, social 
and environmental indicators are calculated. As a result of the calculations performed, it was found that social indicators occupy the second place in importance in assessing the results of the enterprise as a whole. In the study of the filling of the social package of Ukrainian enterprises, it was found that the largest part is the cost of participation in trainings, education and advanced training (30\% - one third of the total social package), therefore, it is recommended to increase the cost of insurance for the lives of workers by reducing educational expenses.

\section{REFERENCES}

Albinger, H.S., \& Freeman, S.J. (2000). Corporate Social Performance and Attractiveness as an Employer to Different Job Seeking Populations. Journal of Business Ethics, 28(3), 243253.

Aliekperova, N. (2018). Motivating factors effecting work efficiency of employees in Ukrainian pharmaceutical sector. Economics \& Sociology, 11(1), 61-73.

Barth, R., \& Wolff, F. (2009). Corporate social responsibility in Europe: Rhetoric and realities. Edward Elgar Publishing.

Berling, R. (2012, September 22). Ecological and economic losses and their relationship between notion expenses and costs for enterprises operating under development innovation. Retrieved from http://archive.nbuv.gov.ua/portal/natural/vnulp/logistyka /2012_749/01.pdf

Bilan, Y., Mishchuk, H., \& Pylypchuk, R. (2017). Towards sustainable economic development via social entrepreneurship. Journal of Security \& Sustainability Issues, 6(4), 161- 245.

Blowfield, M., \& Murray, A. (2011). Corporate Responsibility. Oxford: Oxford University Press.

Carroll, A. B. (1999). Corporate Social Responsibility: Evolution of a Definitional Construct. Business \& Society, 38(3), 268-295.

Chen, T., Dong, H., \& Lin, C. (2019). Institutional Shareholders and Corporate Social Responsibility. Journal of Financial Economics, 135(2), 483-504. doi:10.1016/j.jfineco.2019.06.007.

Crestofel, D., Shaniqua, L., Pulungan, A., \& Yudiarti, D. (2017). Analyzing the effectiveness of a joint corporate social responsibility program to empower people in an Indonesian village. International Journal of Business and Society, 18(S2), 323-338.

Dahlsrud, A. (2008). How corporate social responsibility is defined: an analysis of 37 definitions. Corporate Social Responsibility and Environmental Management, 15(1), 31-48.

European Commission (2002), European SMEs and social and environmental responsibility Belgium: Observatory of European SMEs 2002/No. 4

Frederick, C. William. (2018). Corporate Social Responsibility: From Founders to Millennia's. Corporate Social Responsibility, 28(3), 1-3.

Gjølberg, M. (2009). Measuring the immeasurable? Constructing an index of CSR practices and CSR performance in 20 countries. Scandinavian Journal of Management, 25(1), 10-22.

Grover, P., Kar, A. K., \& Ilavarasan, P. V. (2019). Impact of corporate social responsibility on reputation-Insights from tweets on sustainable development goals by CEOs. International Journal of Information Management, 48, 39-52. doi: 10.1016/j.ijinfomgt.2019.01.009.

Institute of Chartered Accountants in England And Wales (1975). The Corporate Report. London: ICAEW.

International Accounting Standard 19 (IAS 19) «Employee benefits» (2012). Retrieved from http://zakon3.rada.gov.ua/laws/show/929_011 
Kot, S. (2014). Knowledge and Understanding of Corporate Social Responsibility. Journal of Advanced Research in Law and Economics, 2(10), 109-119.

Krepak, D., 2016. Work for society: what is the corporate social responsibility of business. To consider it as unacceptable luxury or vital necessity?, Retrieved from http://forbes.net.ua/ua/opinions/1413277-pracyuvati-na-suspilstvo-shcho-takekorporativna-socialna-vidpovidalnist-biznesu.

Krisnawati, A., Yudoko, G., \& Bangun, Y.R. (2018). Modeling an effective corporate social responsibilitybased on systems theory and management functions: a case study in Indonesia. International Journal of Business and Society, 19, 249-261.

Kunz, V., Ferencová, M., Hronová, Š., \& Singer, M. (2015). Researching of Socially Responsible Behavior in selected Companies and Organizations through their Corporate Websites. Polish Journal of Management Sciences, 12(2), 91- 102.

Labour Code of Ukraine: approved by the Law of Ukraine of December 10 ${ }^{\text {th }}, 1971$, No. 322-VIII (1971). Retrieved from http://zakon5.rada.gov.ua/laws/show/322-08

Luo, W., \& Bhattacharya, C.B. (2006). Corporate Social Responsibility, Customer Satisfaction, and Market Value, Journal of Marketing, 70(4),1-14.

Mahoney, L.S., \&Thorne, L. (2005). Corporate Social Responsibility and Long-term Compensation: Evidence from Canada. Journal of Business Ethics, 57(3), 241-253

Mauricio Andrés, L. A., Lára, J., \& Brynhildur, D. (2019). Drivers that motivate energy companies to be responsible. A systematic literature review of Corporate Social Responsibility in the energy sector. Journal of Cleaner Production, 247(20), 119094. doi: 10.1016/j.jclepro.2019.119094.

Mohamed Adnan, S., Hay, D., \& van Staden, C. J. (2018). The influence of culture and corporate governance on corporate social responsibility disclosure: A cross country analysis. Journal of Cleaner Production, 198, 820-832. doi: 10.1016/j.jclepro.2018.07.057.

Nwabueze, U., \& Mileski, J. (2018). Achieving competitive advantage through effective communication in a global environment. Journal of International Studies, 11(1), 50-66.

Ogrean, C. (2014). Perceptions on the strategic value of corporate social responsibility - some insights from global rankings. Journal of International Studies, 7(2), 128- 140.

Oliinyk, O. O. (2017). Corporate social responsibility in the field of occupational safety and health. Scientific Bulletin of National Mining University, 2, 128-133.

On Remuneration of Labour Act: The Law of Ukraine of March 24 ${ }^{\text {th }}$, 1995, No. 108/95-VR (1995) , Retrieved from http://zakon4.rada.gov.ua/laws/show

Orlitzky, M., Schmidt, F. L., \& Rynes, S. L. (2003). Corporate Social and Financial Performance: A Meta-Analysis.Organization Studies, 24(3), 403-441.

Osadcha, O., \& Svirko, S. (2014). Category of "economic benefit" as the estimates of revenue and expenditure. Economic Annals, 21(1-2), 30-33.

Park, K., Meglio, O., \& Schriber, S. (2019). Building a global corporate social responsibility program via mergers and acquisitions: A managerial framework. Business Horizons. doi:10.1016/j.bushor.2019.01.006.

Porter, M. E., \& Kramer, M. R. (2006). The link between competitive advantage and corporate responsibility. Harvard Business Review, 84(12), 78-92.

Rodriguez-Fernandez, M. (2016). Social responsibility and financial performance: The role of good corporate governance. Business Research Quarterly, 19(2), 137-151.

Stahl, G. K., Brewster, C. J., Collings, D. G., \& Hajro, A. (2019). Enhancing the role of human resource management in corporate sustainability and social responsibility: A multi- 
stakeholder, multidimensional approach to HRM. Human Resource Management Review, 30(2), 100708. doi: 10.1016/j.hrmr.2019.100708.

The Code of Labour Law Draft, No. 1658 of December $27^{\text {th }}$, 2014 (2014). Retrieved from http://w1.c1.rada.gov.ua/pls/zweb2/webproc4_1?pf3511=53221

Turker, D. (2008). Measuring Corporate Social Responsibility: a scale development study, Journal of Business Ethics, 85(4), 411-427.

Sukserm, T., \& Takahashi, Y. (2011). Effects of Individual Characteristics on Learning Through Human Resource Development in Corporate Social Responsibility Activity. International Journal of Business and Society, 12(2), 87-100.

Ukrainian Generally Accepted Accounting Principles 26 «Employee benefits»: Ukrainian Ministry of Finance Act of October 28th, 2003, No. 601 (2003). Retrieved from http://zakon2.rada.gov.ua/laws/show/z1025-03

Vasilescu R., Barna C., Epure M., \& Baicu C. (2010). Developing university social responsibility: A model for the challenges of the new civil society. Procedia - Social and Behavioral Science, 2(2), 4177-4182. doi: https://doi.org/10.1016/j.sbspro.2010.03.660

Vveinhardt, J., \& Andriukaitiene, R. (2017). Management Culture as Part of Organizational Culture in the Context of Corporate Social Responsibility Implementation. Economics and Sociology, 10(3), 294-320.

Waddock, S. A., \& Graves, S. B. (1997). The corporate social performance-financial performance link. Strategic Management Journal, 18(4), 303-319.

Xiao, M., Cooke, F. L., Xu, J., \& Bian, H. (2019). To what extent is corporate social responsibility part of human resource management in the Chinese context? A review of literature and future research directions. Human Resource Management Review, 30(4), 100726. doi: 10.1016/j.hrmr.2019.100726. 